\title{
Inflation Target In Emerging Countries: Modeling Exchange Rate Issues*
}

Javier A. Reyes, (E-mail: jreyes@econ.tamu.edu), Texas A\&M University

\begin{abstract}
The idea of inflation targeting in emerging countries is not a new one. There have been papers that favor or reject the idea of implementing such a system in these countries for mainly institutional reasons. This paper does not deal with these normative arguments. Emerging countries are implementing IT regimes and therefore it is necessary to understand how it should be done and what problems can arise. Therefore this paper focuses on exchange rate issues for inflation targeting. These issues have their root in the basic relation that exists in emerging countries between inflation and the exchange rate, a relation known as the "pass through effect". The simple setup used in this paper shows how the monetary authorities implementing an IT regime must intervene in the exchange rate market in order to comply with the inflation target. The central bank intervenes in order to avoid exchange rate movements that would affect the overall inflation rate through the pass-through effect. These results mean that the dirty floating or fear of floating hypothesis should be modified when applied to countries implementing IT, since their intervention (or dirty floating activities) may be justified.
\end{abstract}

\section{Introduction}

D uring the early nineties the literature on Inflation Targeting (IT) focused on analyzing IT regimes in industrialized countries like New Zealand, Canada, the United Kingdom and Sweden ${ }^{1}$. The literature focus changed after the currency crises of the mid and late nineties, when several emerging countries were forced to abandon their fixed exchange rate regimes and some countries like Brazil, Czech Republic and Thailand, decided to introduce IT as their new monetary policy framework. Now current studies deal with the question of how possible and recommendable IT, as a monetary policy regime, is for emerging countries.

The initial approach was to check how well these countries fulfill the minimum requirements to implement IT regimes. IT has specific requirements which include the announcement of a numerical target for the inflation rate (a point or range), a strong commitment to price stability as the main objective of the central bank or monetary authorities and central bank independence accompanied by a more transparent and effective communication with the public and the markets, detailing the instruments that will be used to achieve the inflation target.

Arguments emerged for and against the implementation of IT in emerging countries. Masson, Savastano and Sharma (1997) claimed that most of the emerging countries considering the implementation of IT did not fulfill the basic requirements. They argued that many countries did not have an independent central bank while the heavy dependence of their government revenue on seigniorage precluded them from having a firm commitment to a low inflation rate as the overriding objective their monetary policy. Further, the necessary flexibility of the exchange rate may not be possible since exchange rate movements affect the economy through various channels. More recent studies however, like Mishkin and Savastano (1999) and Agenor (2000) concluded that some medium and high income emerging countries may be able to implement IT, specifically those with a relatively low initial inflation rate, reasonably well-functioning financial markets and those that can refrain from implicit exchange rate targeting.

\footnotetext{
I am grateful to Leonardo Auernheimer, Christopher Ball, and Pablo Gonzalez for their insightful comments, although some of their insights may not be fully reflected in the paper.

${ }^{1}$ Bernanke, B.S., Laubach, T., Mishkin, F.S. and Posen A.S. (1999), “Inflation Targeting” Princeton: Princeton University Press.
} 
There are other inconclusive arguments concerning the advantages and disadvantages of IT. One of the advantages is that IT increases the accountability of the central bank and reduces the incentives for time inconsistent policies since the public observes the realized inflation rate. The biggest disadvantage is that IT is heavily dependent on inflation forecasting accuracy, which is a difficult task in emerging countries.

Over the past 5 years the number of emerging countries implementing IT regimes continued to increase. Currently Brazil, Chile, Colombia, Czech Republic, Hungry, Korea, Mexico, Peru, Poland, Thailand are all using IT as their monetary policy regime. ${ }^{2}$ Given the strong pace of adoption, the literature is increasingly interested in the technical issues. The discussion seems to be mainly around two well-known subjects: "fiscal dominance" and the "exchange rate".

Fiscal dominance is characterized by high levels of government deficits and a strong dependence of government revenue on seigniorage. It is important to note that the effects and inconsistencies of fiscal dominance are the same under any regime. Therefore the conclusion under IT is very similar to that of other regimes. Governments pursuing persistent and significant fiscal imbalances under inflation targeting regimes will eventually cause the collapse of the program; fiscal imbalances will have to be monetized or sudden and large depreciations will be used to erode public debt followed by high levels of inflation. ${ }^{3}$

In contrast to public deficit problems, exchange rate issues appear particularly relevant for IT regimes in emerging countries given the high level of pass through effects from exchange rate movements to inflation in these countries. Further, these countries have a tendency to display high levels of dollarization. For these two reasons it is important to notice that the monetary authorities can't ignore the behavior of the exchange rate when conducting inflation targeting. These specific issues, which have been identified for quite some time now, are the ones for which there seems to be no definite conclusions in the literature. Several authors ${ }^{4}$ have pointed out the importance of their effects and their implications for IT regimes. Except for Kumhof, M. Li, S. and Yan, I. (2001), and Gali and Monacelli (2002) thus far the argument seems to be one of merely describing the problem rather than addressing how to deal with it.

Another matter of contention related to the exchange rate issues is the one that has emerged from another literature trend, one that has been termed "dirty floating" or "fear of floating". Here many of the countries that have declared IT as their monetary framework have been analyzed as countries that claim to have flexible exchange rate regimes but intervene directly or indirectly in the foreign exchange market. In other words they have been found to behave as "dirty floaters". Relevant studies in this trend have been those by Calvo and Reinhart (1999) Reinhart (2000) and Lahiri and Vegh (2000b). The conclusions arising from this literature are that for different reasons these countries do not let their currencies float as they claim. One reason being the pure fear of floating, where the policy makers do not let their currency depreciate or try to avoid exchange rate volatility, this is Calvo and Reinhart's argument. Another reason, shown by Lahiri and Vegh, is that the monetary authorities intervene in the exchange rate market to avoid output fluctuations.

Whatever the conclusions in this literature, something seems to be missing regarding countries implementing IT regimes. Many of the countries mentioned in Calvo and Reinhart's analysis actually claim to be implementing IT regimes. And this has different implications and conclusions for the intervention of the central bank in the foreign exchange market. Ball and Reyes (2002) have shown, with statistical analysis similar to that in Calvo and Reinhart's paper, that the dirty floating hypothesis should be modified when applied to IT countries.

The objective of this paper lies in the analysis of exchange rate issues within an IT regime. Kumhof, M. Li, S. and Yan, I. (2001) as well as Gali and Monacelli (2002) have dealt with these issues in two different ways. The first paper analyzes the vulnerability of IT regimes to speculative attacks. The authors motivate the study by assuming that at a certain point in time the government begins pursuing an inconsistent monetary-fiscal policy mix.

\footnotetext{
${ }^{2}$ Mishkin and Schmidt-Hebbel (2001).

${ }^{3}$ See Mishkin (2000) and Kumhof (2000) for more on this issue.

${ }^{4}$ Mishkin(2000), Agenor (2000), Eichengreen(2001), Carstens and Werner (1999), Garcés (1999).
} 
Even though this approach is more related to the fiscal dominance issue, the model uses exchange rate pressure on the overall inflation rate to motivate the argument of vulnerability and the necessary intervention by the monetary authorities in the foreign exchange market in order to reduce the exchange rate pressure.

Using a small open economy model, Gali and Monacelli analyze and compare three monetary policy regimes: domestic inflation targeting, CPI targeting and an exchange rate peg. This approach is similar to the one use in this paper. The response of the monetary authorities to domestic and foreign productivity shocks under each regime has different effects on the real and nominal exchange rates resulting in different volatility levels of the exchange rate and different output and inflation gaps. Given these results the authors use welfare analysis to rank the regimes. In their conclusions they note that domestic inflation targeting dominates the other two in terms of welfare.

With a model of a small open economy the study shows the differences between an IT regime and a policy regime where the central bank lets the exchange rate float and fixes the rate at which the money stock grows. Afterwards, exchange rate movements due to changes in the money stock and in the rate of growth of the nominal money stock are studied and the important differences arising from these experiments are analyzed. The results show that having an IT commitment will force the monetary authorities to intervene in the foreign exchange rate market. This intervention however is not the result of dirty or fear of floating practices or output fluctuations. Rather, it is justified as a requirement to achieve the inflation target. It also shows that there are important differences in the behavior of different variables like money demand, consumption output and, of course, inflation. These are important when analyzing the policy implications of the different regimes, as well as in the section of welfare analysis.

Section II presents the setup for the model, it also offers a brief analysis of exchange rate pressure on inflation and elaborates on the solution of the model, for the IT case and for the alternative policy regime The thought experiments used to analyze the exchange rate issues are presented in section III. Finally section IV concludes the paper and summarizes the results.

\section{The Model}

The model is a continuous time representative agent model for a small open economy based on Auernheimer and George (2000), where the private sector produces two types of goods, traded and non-traded, $x_{T}$ and $x_{H}$ respectively. ${ }^{5}$ Consider the problem for the representative individual that lives forever and where the world price for the traded good is constant.

\subsection{Consumers}

Consumers maximize lifetime utility derived from the consumption of traded and non-traded goods, $c_{T}$ and $c_{H}$, respectively. They also hold money, $M$, and net foreign assets, $a^{I}$, denominated in terms of foreign currency that yield the world interest rate, $r$. Real money balances, $m$, enter the utility function because of the liquidity services they provide. The utility function is:

$$
\int_{0}^{\infty} U\left(c_{T}, c_{H}, m\right) e^{-\rho t}
$$

where $m=M / P_{H}$. The utility function is assumed to be separable, concave and twice continuously differentiable.

Consumers pay taxes, $T$, also given. Let $P_{T}, P_{H}, P^{*}{ }_{T}$ and $E$ denote the domestic price level for the traded good, domestic price level for the non-traded good, foreign price level of the traded good and the exchange rate,

\footnotetext{
${ }^{5}$ Based on the model of Auenrheimer and George (2000). The main modification to their setup is the addition of the inflation target constraint to the system, when the differences between IT and the monetary rule regime are analyzed.
} 
respectively. If we define the real exchange rate as $P_{T} / P_{H}$, assuming instantaneous arbitrage in commodities, $P_{T}=E$ $P_{T}^{*}$ and letting $P_{T}^{*}=1$, then the individuals flow budget constraint in terms of the tradable good is:

$$
x_{T}+\frac{x_{H}}{\varepsilon}+a r=c_{T}+\frac{c_{H}}{\varepsilon}+T+\dot{m} \frac{1}{\varepsilon}+m \pi \frac{1}{\varepsilon}+\dot{a}
$$

where $\varepsilon$ represents the real exchange rate and $\hat{E}$ denotes the depreciation rate of the domestic currency.

The problem for the typical individual is to maximize [1] subject to [2] by choosing the optimal values for the consumption of traded and non-traded goods, real money balances and net foreign asset holdings, taking as given the world interest rate $r$, the endowments and the level of taxes.

The resulting optimality conditions are:

$$
\begin{array}{r}
\frac{U_{T}}{U_{H}}=\varepsilon \\
U_{m}=U_{H}(\rho+\hat{E}) \\
\dot{c}_{T}=\frac{U_{T}}{-U_{T T}}(r-\rho)
\end{array}
$$

where $U_{H}, U_{T}$ and $U_{m}$ represent partial derivatives of the utility function with respect to consumption of the nontraded and traded goods, and real money holdings. And $\dot{c}$ denotes $\mathrm{dc}_{\mathrm{t}} / \mathrm{dt}$.

Equation [3] equates the marginal rate of substitution between traded and non-traded goods to their relative prices. Using [4] and [5], the marginal optimal condition between real money holdings and traded goods is:

$$
\frac{U_{m}}{U_{T}}=\frac{r+\hat{E}}{\varepsilon}
$$

\subsection{Inflation}

Let the price index used be a combination of traded and non-traded goods price levels:

$$
P=P_{T}^{\theta} P_{H}^{1-\theta}
$$

Using [7] and recalling the assumption of instantaneous arbitrage in commodities the overall inflation rate can be expressed as:

$$
\Pi=\theta \hat{E}+(1-\theta) \pi_{H}
$$

Short run price rigidity of the non-traded good is assumed ${ }^{6}$. This introduces friction into the model in a simple and tractable way. The non-traded good inflation rate is defined as follows:

$$
\pi_{H}=\delta \hat{E}^{a}+\gamma\left(\varepsilon-\varepsilon^{*}\right)
$$

where $\hat{E}^{a}$ represents the expected rate of depreciation and $\varepsilon^{*}$ denotes the equilibrium real exchange rate that corresponds to a consumption level of the non-traded good, net of government consumption, that is equal to the long

${ }^{6}$ Following Auernheimer and George (2000) 
run production level, $\mathrm{x}_{\mathrm{H}}^{*}$, defined exogenously. Then the production of these goods will be demand determined given the level of the real exchange rate.

Using [9] the proportional rate of change for the real exchange rate (i.e. $\mathrm{d} \varepsilon / \mathrm{dt} 1 / \varepsilon$ ) will be:

$$
\hat{\varepsilon}=\hat{E}-\delta \hat{E}^{a}-\gamma\left(\varepsilon-\varepsilon^{*}\right)
$$

Finally incorporating the sluggishness of the non-traded good price into the overall inflation rate [8], the final expression is the following:

$$
\Pi=\theta \hat{E}+(1-\theta) \delta \hat{E}^{a}+\gamma(1-\theta)\left(\varepsilon-\varepsilon^{*}\right)
$$

\subsection{Government.}

Government expenditures include consumption of traded and non-traded goods, $g_{\mathrm{T}}$ and $g_{\mathrm{H}}$, respectively and changes in it's holding of foreign assets, $a^{g}$. Revenue consists on interest earned on holdings of foreign assets, seigniorage from money creation and tax revenues. The government budget constraint is the following:

$$
a^{g} r+\frac{T}{\varepsilon}+\dot{m}+m \hat{E}=g_{T}+\frac{g_{H}}{\varepsilon}+\dot{a}^{g}
$$

\subsection{Aggregate Budget Constraint} payments:

Aggregating the government and the private sectors' budget constraint yields the country's balance of

$$
\dot{w}=w r+x_{T}-c_{T}-g_{T}
$$

where $w=a^{G}+a^{I}$, representing the country's net foreign assets.

\subsection{Analyzing Exchange Rate Pressure On Inflation}

Equation [11] determines the overall rate of inflation as a function of the actual depreciation rate, the expected depreciation rate and the difference between the real exchange rate and its long-run equilibrium. Assuming perfect foresight, the expected rate of depreciation will equal the actual rate, $\hat{E}^{a}=\hat{E}$. This affects two of the above equations. First the proportional rate of change of the real exchange rate, equation [10], becomes:

$$
\hat{\varepsilon}=(1-\delta) \hat{E}-\gamma\left(\varepsilon-\varepsilon^{*}\right)
$$

and the overall inflation rate, equation [11], becomes:

$$
\Pi=(\theta(1-\delta)+\delta) \hat{E}+\gamma(1-\theta)\left(\varepsilon-\varepsilon^{*}\right)
$$

Using equation [15] one can look at how exchange rate movements are translated directly into inflationary pressure. There are two channels, changes in the level of the exchange rate and changes in the rate of depreciation.

Looking at the first channel, a sudden increase in the level of the nominal exchange rate, the initial effect is an increase in the level of the real exchange rate. Given the assumed dynamics of the non-traded good price, overall inflation increases. This is the result of the price of the non-traded good catching up with the increase in the price of the traded good. During the adjustment period the rate of change of the non-traded good price will be higher than 
the rate of depreciation, taking the real exchange rate back to its long-run equilibrium level. In the end, the overall inflation rate will be the same as it was before the shock.

Now consider an increase in the rate of depreciation. If the monetary authorities do not intervene in the foreign exchange market the overall inflation rate would be above the equilibrium level and the commitment would be broken.

From the standpoint of a central bank strictly implementing an IT regime, the two cases, a change in the level of the exchange rate or a change in the rate of depreciation, will force the intervention of the central bank. Both scenarios have different effects in the economy, but for the central bank the result is the same, the inflation target is broken. Exchange rate pressure works its way either directly to the overall inflation rate when the depreciation rate changes or through the change of the non-traded goods price when there is a level change of the nominal exchange rate. This simple analysis suggests that if the monetary authorities want to strictly fulfill the inflation target they must respond to changes in the exchange rate. Then the question that needs to be answered is how the monetary authority intervenes in the foreign exchange market.

\subsection{Solving the Model}

Recalling equation [5] and assuming that the rate of time preference is equal to the world real interest rate, then in the absence of changes in the parameters the level of traded good consumption adjusts immediately to the level at which the change in the country's net foreign assets is equal to zero, $\dot{w}=0$, that is:

$$
c_{T_{o}}=w_{o} r+x_{T}-\bar{g}_{T}
$$

where $w_{o}$ is the level of the country's net foreign assets given by past history and $\bar{g}_{T}$ is constant and given exogenously. Using equation [16] and a given the level of the real exchange rate, then the level of consumption and production for the non-traded good is implicitly determined by equation [3] and the market clearing condition for the non-traded good sector, $\mathrm{x}_{\mathrm{H}}=\mathrm{c}_{\mathrm{H}}$.

There is a need to define what exactly the monetary authorities fix. In other words what the anchor for the monetary policy is. For IT the anchor is the target itself. Some other instrument is used to maintain the target. For the current simple model, it is assumed that this instrument is the rate of growth of the nominal money supply. This simple approach will allow the comparison of the results from IT with those obtained from a system where the anchor is the rate of growth of the nominal money stock.

It is important to clarify that for the "IT case", the central bank first sets the inflation target and then determines what rate of growth for the nominal money stock is consistent with this target. In the other case, from here on referred to as the "monetary case", the central bank sets the rate of growth of the nominal money stock without taking anything else into account.

Given the definition of real money holdings, $m=M / P_{H}$, the equation of motion for real money holdings is:

$$
\frac{\dot{m}}{m}=\mu-\pi_{H}
$$

where $\mu$ denotes the rate of growth of the nominal money stock. Using equation [9] to plug in for $\pi_{H}$ and plugging in the result that is obtained from isolating $\hat{E}$ from equation [6], then equation [17] can be rewritten as follows:

$$
\frac{\dot{m}}{m}=\mu+r+\gamma\left(\varepsilon^{*}-\varepsilon\right)-\frac{U_{m} \varepsilon}{U_{T}}
$$




\subsection{Monetary Case}

When the monetary authorities are using a monetary rule to anchor the system, meaning they only set the growth rate of the nominal money stock. The system of differential equations that is used to determine the real exchange rate and the growth rate of the nominal money stock is comprised of equations [14] and [18]. After linearizing the system, two roots of opposite sign are found assuring a unique saddle path. Figure [1] illustrates the system, where it has been assumed that $\delta=1$. Using the path of adjustment for the real exchange rate and real money balances in conjunction with the fact that the consumption of traded goods adjusts immediately, it is possible to calculate the equilibrium levels for consumption of traded and non-traded goods as well as for the inflation rate and the depreciation rate.

\subsection{IT Case}

When the central bank implements an IT regime, it first sets the overall inflation rate target and then sets and then uses its monetary policy tools to comply with this target. In this case the tool consist on direct intervention in the foreign exchange market once there is a shock that takes the system out of equilibrium ${ }^{7}$. After the shock takes place, the authorities will use international reserves to control the currency depreciation. They will set a path for the nominal exchange rate that is consistent with the inflation target. It is important to notice that IT is indistinguishable from exchange rate targeting during the adjustment period, therefore the rate of depreciation is exogenously determined while the level of nominal money stock becomes endogenous. Under this environment equation [6] denotes the relation that holds at all times between the real exchange rate and the nominal money stock, while equation [14] still determines the adjustment path for the real exchange rate. Again, given this adjustment it is possible to calculate the levels of consumption of traded and non-traded goods.

\section{Thought Experiments}

In order to show the differences between the two cases this section goes through two thought experiments. One that affects the level of the exchange rate due to a once and for all change in the nominal money stock. The second one deals with a change in the depreciation rate due to a change in the inflation target for the IT case and a change in the rate of growth of the nominal stock for the monetary case. In both cases, without loss of generality, government consumption of the traded and non-traded goods is assumed to be zero.

The explicit utility function used is the following:

$$
U=\alpha \ln c_{T}+\beta \ln c_{H}+\sigma \ln m
$$

\footnotetext{
${ }^{7}$ It is possible to illustrate the intervention by using the central bank balance sheet, that in this case is represented by $E \cdot R=M$, where $E$ represents the nominal exchange rate, $R$ denotes the international reserves held by the central bank and $\mathrm{M}$ is the nominal money stock. Rearranging this expression in order to have it in terms of the non-traded good, since real money balances are defined in terms of the non-traded good, and isolating $E$ the following is obtained $E=m \cdot P_{H} / R$. When the central bank controls the nominal exchange rate, $m$ is endogenously determined. Therefore for a given level of $m$ determined by equation [6], taking into account the path for the nominal exchange rate consistent with the inflation target, the central bank adjusts the level of international reserves in order to maintain or adjust $E$ to the consistent level with the inflation target.
} 
The value for the parameters used in the simulations of the thought experiments are listed in the following table:

Table 1. Thought Experiments Parameters

\begin{tabular}{|c|c|c|c|}
\hline Parameter & Initial Value & Parameter & Initial Value \\
\hline$\alpha$ & 0.30 & $\varepsilon^{*}$ & Error! Not a valid link..0 \\
\hline$\beta$ & 0.40 & $\theta$ & Error! Not a valid link. \\
\hline$\sigma$ & 0.30 & $\mathrm{r}$ & 0.05 \\
\hline$\gamma$ & 0.80 & $\mathrm{a}^{\mathrm{I}}$ & -10.0 \\
\hline$\delta$ & 1.00 & $\mathrm{a}^{\mathrm{g}}$ & 20.0 \\
\hline $\bar{\Pi}$ & Error! Not a valid link. & $\mathrm{g}_{\mathrm{H}}$ & 0.00 Error! Not a valid link. \\
\hline Error! Not a valid link. & Shock in $\mathrm{t}=$ & 6Error! Not a valid link. \\
\hline
\end{tabular}

\subsection{Level Change}

The change in the level of the exchange rate is caused by a once and for all $10 \%$ increase in the level of the nominal money stock. Due to its sluggish nature the non-traded good price cannot adjust immediately, there will be a mismatch between demand and supply of real money balances. Individuals will try to lower their money holdings but as they do so, due to the existence of a flexible exchange rate, they will cause a jump in the parity of the domestic currency with respect to the foreign one. This situation will correspond to a higher, out of equilibrium, real exchange rate. The difference between the actual and the equilibrium real exchange rate will cause higher inflation for the non-traded good. If the monetary authorities do not react to this inflationary pressure, the overall inflation rate will start rising, which means that for the IT case the target won't be met.

Figure [2] depicts the adjustment path, for the Inflation Targeting (IT) and the monetary case (MC), of the real exchange rate, money demand, depreciation rate, overall inflation rate and consumption of the non-traded good. The diagrams show that when there is an IT regime in place the monetary authorities have to react and offset the inflationary pressure by intervening in the foreign exchange market. Therefore the domestic currency depreciates at a rate that is low relative to the steady state equilibrium rate. By doing so the central bank is complying with the inflation target at every point in time. For the monetary case inflation will rise at the beginning and return to the old equilibrium level as the gap between the actual and steady state real exchange rate is reduced.

The reaction of the central bank to maintain its inflation target forces the system back into the same steady state equilibrium that is achieved under the monetary case. But this is at the expense of variation in the exchange rate and the money demand levels. Trying to analyze these variations in order to see which system may be more beneficial, the utility function of the representative individual and a loss function for the central bank are evaluated under both cases. Figure [2] includes a diagram for the loss function of the central bank and the consumers' level of utility. The loss function is calculated by squaring the differences between the current and equilibrium output and inflation levels and adding them up.

The conclusion that can be obtained from the loss function is that the reaction of the central bank in the IT case reduces the output volatility and completely avoids any inflation misalignments so that the loss is less in this case. Analyzing the situation from the view point of individuals, it is possible to see that the utility obtained from consumption and money holdings is higher for the IT case.

\subsection{Rate Change}

The change in the depreciation rate of the domestic currency is caused by the central bank changing its inflation rate target in the IT case from $6.0 \%$ to $8.0 \%$, or equivalently in the monetary case changing the growth rate of the nominal money stock. Recalling equation [15] and the assumption of fully flexible exchange rate, the rate of depreciation will adjust immediately after the change in the growth rate of the money stock. Under both cases, the 
monetary rule and IT, individuals know that in steady state the inflation rate will be higher, and this will correspond to a lower demand for real money balances, causing again a mismatch between demand and supply of real money balances and consequently the initial jump of the nominal exchange rate as individuals try to adjust their money holdings. In other words the change in the inflation target or the rate of growth for the nominal money stock moves the $\dot{m}=0$ line depicted in figure [1] to the left.

Under the monetary case the nominal exchange rate will jump to the level at which the system reaches the new saddle path, and then the real exchange rate and the real money holdings will follow the dynamic equilibrium determined by the unique saddle path. Regarding the IT case, given the commitment to meet the inflation target, the adjustment will be different, the central bank will have to intervene in the foreign exchange market in order to maintain or adjust the nominal exchange rate to a level that is consistent with the inflation target.

Recalling the assumption made about the sluggish response of the non-traded good price level, it can be seen that when the central bank sets a higher inflation target the depreciation rate can adjust instantly but the nontraded good inflation can not, therefore the realized overall inflation rate would be higher than the target. In order to comply with the target, the monetary authorities must initially lower the currency depreciation, relative to the new steady state equilibrium. As the non-traded good price adjusts and the real exchange rate approaches its steady state equilibrium, the intervention will allow a higher rate of depreciation.

As was expected, rate changes translate into new steady state equilibrium levels for consumption of nontraded and traded goods, as well as real money holdings. This is depicted in figure [3], where the variables adjust towards a new equilibrium after the adjustment process is over. Also, just as in the level change case, the ability of the central bank to intervene under the IT case allows the authorities to stabilize the system at the same steady state as in the monetary case, with lower values for the loss function and with higher variations in the money demand and the depreciation rate. Finally, from the individual's point of view the story is the same as in the previous experiment, the utility level under the monetary case is lower than under IT.

\section{Conclusion}

The idea of inflation targeting in emerging countries is not a new one. There have been papers that favor or reject the idea of implementing such a system in these countries for mainly institutional reasons. This paper does not deal with these normative arguments. Emerging countries are implementing IT regimes and therefore it is necessary to understand how should it be done and what problems can arise. Therefore the paper focus on exchange rate issues for inflation targeting. These issues have their root in the basic relation that exists in emerging countries between inflation and the exchange rate. Relation known as the "pass through effect".

The simple setup used in this paper shows how the monetary authorities implementing an IT regime must intervene in the exchange rate market in order to comply with the inflation target. The central bank intervenes in order to avoid exchange rate movements that would affect the overall inflation rate through the pass-through effect. These results mean that the dirty floating or fear of floating hypothesis should be modified when applied to countries implementing IT, since their intervention (or dirty floating activities) may be justified.

It is important to note that even though the analysis presented in this paper seems to favor IT regimes for emerging markets, these results would be exactly the opposite if the shocks were in the other direction. Also these conclusions may be the result of the costless intervention of the central bank. In other words the monetary authorities have a way to intervene in the market without introducing any other distortions in the system. This would not be the case when the production side of the economy is modeled in a more realistic and complete setup, one in which the nominal interest rate plays a role in determining the level of production and therefore affecting consumption as well.

Future research should expand the issues presented here in a more complete and perhaps more realistic setup. One that includes a wider set of monetary policy tools. Currently the instruments of choice for central banks implementing IT regimes are usually international reserves, the money supply and the interest rate. Ideally the 
model will show what the consequences, if any, are of using one or the other, or perhaps a combination of them, whether there is an optimal mix and perhaps what the possible fiscal implications are. This setup should also model the production side explicitly so the monetary policy transmission mechanisms play a role in the dynamics of the model.

\section{Reference}

1. Agénor, Pierre-Richard. (2000), "Monetary Policy under Flexible Exchange Rates: An Introduction to Inflation Targeting", World Bank.

2. Auernheimer, L. and George, S.M. (2000), "Bad Dreams Under Alternative Anchors: Are the Consequences Different?", IMF Working Paper, WP/00/20.

3. Banco de Mexico "Exposicion Sobre la Politica Monetaria para 2000" Banco de Mexico.

4. Ball, C. and Reyes. J. (2002), "Inflation Targeting or Fear of Floating in Disguise: The Case of Mexico", Texas A\&M University.

5. Ball, L. (1998), "Policy Rules for Open Economies", Reserve Bank of Australia Research Discussion Paper: 9806, July 1998, 19 pp.

6. Bernanke, B.S., Laubach, T., Mishkin, F.S. and Posen A.S. (1999), "Inflation Targeting" Princeton: Princeton University Press.

7. Calvo, G. and Reinhart, C. (2000) "Fear of Floating” NBER Working Paper 7993.

8. Carstens, A.G. and Werner, A.M. (1999), "Mexico's Monetary Policy Framework Under a Floating Exchange Rate Regime", Documento de Investigacion No. 9905, Banco de Mexico.

9. $\quad$ Edwards, S. (1992), "Exchange Rates as Nominal Anchors", NBER 4246.

10. Eichengreen, B. (2001), “Can Emerging Markets Float? Should They Inflation Target?", University of California, Berkeley.

11. Ericsson, N. and Brouwer, G. (1998), “Modeling Inflation in Australia”, Journal of Business and Economics Statistics, Vol. 16, No.4.

12. Fachada, P. (2001), "Inflation Targeting in Brazil: Reviewing Two Years of Monetary Policy 1999/00“, Working Papers Series, No. 25, Banco Central Do Brasil.

13. Gali, J. and Monacelli, T. (2002) "Monetary Policy and Exchange Rate Volatility in a Small Open Economy". NBER 8905.

14. Garcés, D. (1999), "Determinacion del Nivel de Precios y la Dinamica Inflacionaria en Mexico", Documento de Investigacion No.9907, Banco de Mexico.

15. Kumhof, M. (2000), “Inflation Targeting Under Imperfect Credibility” Stanford University.

16. Kumhof, M. Li, S. and Yan, I. (2001), "Balance of Payment Crises under Inflation Targeting" Mimeo, Stanford University.

17. Lahiri, A. and Vegh, C. (2000a) "Should Interest Rates be Raised to Fight Currency Depreciation?" Mimeo UCLA.

18. Lahiri, A. and Vegh, C. (2000b) "Fighting Currency Depreciation: Intervention or Higher Interest Rates?" NBER Conference on Currency Crises, January 2001.

19. Masson, P.R., Savastano, M.A. and Sharma, S. (1997), "The Scope for Inflation Targeting in Developing Countries", IMF Working Paper WP/97/130.

20. Mishkin, F.S. (2000), "Inflation Targeting in Emerging Countries", American Economic Review, vol. 90, no.2 May 2000, pp $105-109$

21. Mishkin, F.S. and Savastano, M.A. (2001), "Monetary Policy Strategies for Latin America", Journal of Development Economics, vol. 66, no. 2, December 2001, pp.415 - 444.

22. Mishkin, F.S. and Schmidt-Hebbel, K. (2001) "One Decade of Inflation Targeting in the World: What Do We Know and What Do We Need to Know?", NBER 8397.

23. Reinhart, C.M. (2000) "The Mirage of Floating Exchange Rates", American Economic Review, vol. 90, no. 2, May 2000, pp. 65-70 
24. Ryan, C. and Thompson, C. (2000), "Inflation Targeting and Exchange Rate Fluctuations in Australia" Reserve Bank of Australia, Research Discussion Paper 2000-06.

25. Sargent, T.J. and Wallace. (1981) "Some Unpleasant Monetarist Arithmetic" Federal Reserve Bank of Minneapolis, Quarterly Review, 5, 3, Fall.

26. Svensson, L.E.O. (1997) "Inflation Forecast Targeting: Implementing and Monitoring Inflation Targets" European Economic Review, 41 p. 1111 - 1146.

27. Svensson, L.E.O. (2000) “Open Economy Inflation Targeting” Journal of International Economics 50(1) p. $155-183$.

Notes 
Figure 1: System Under The Monetary Case
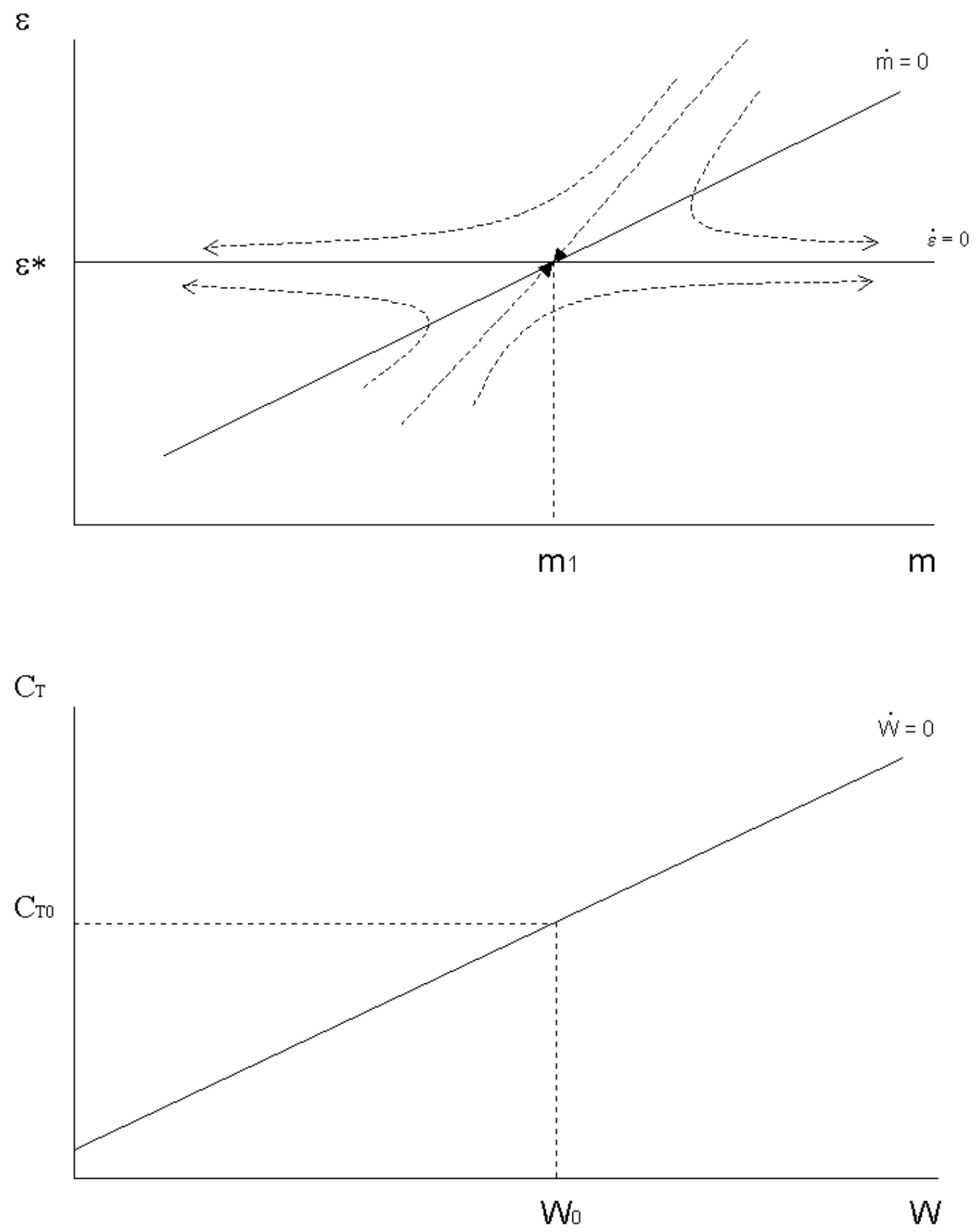
Figure 2. An Increase In The Money Stock
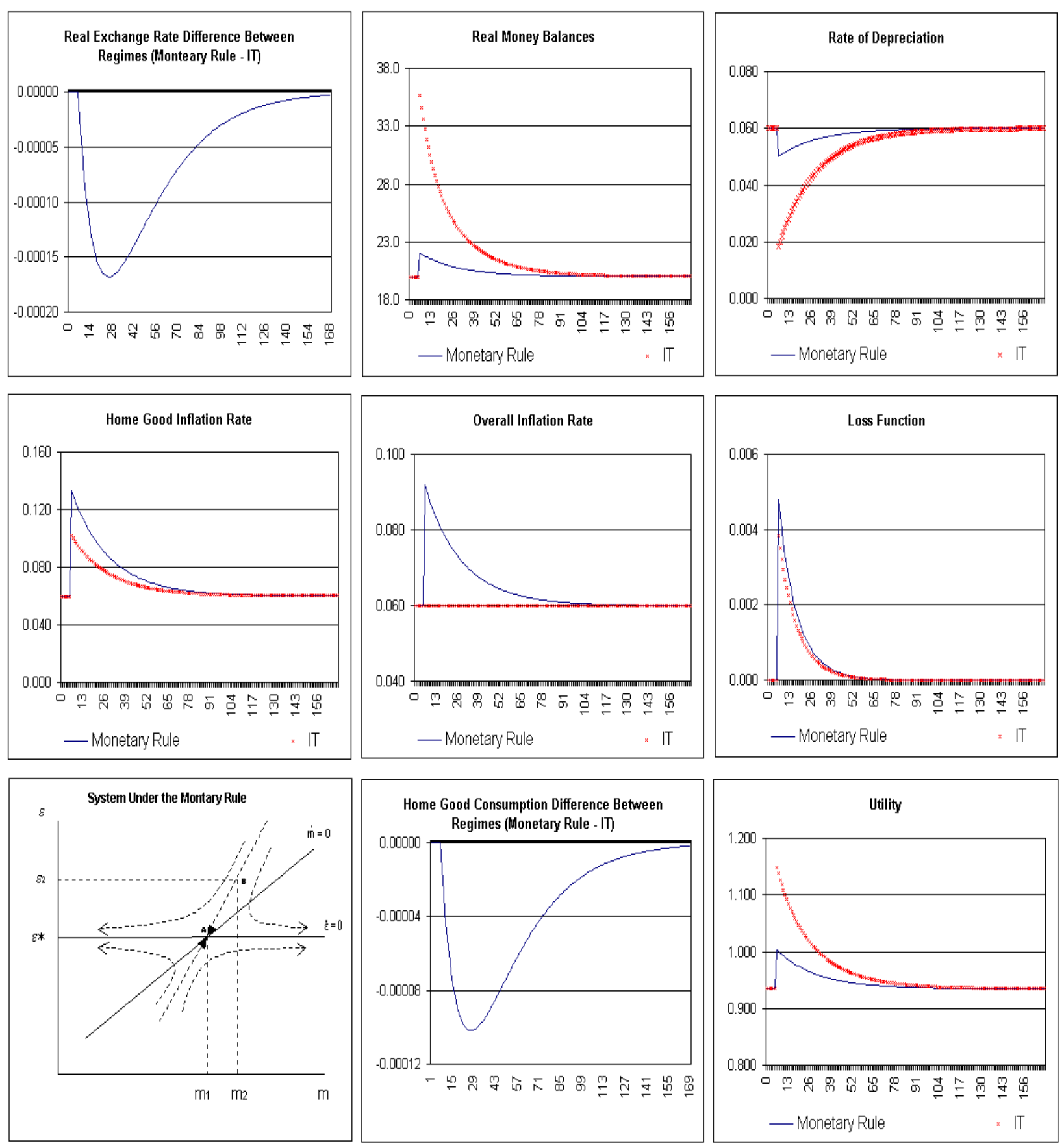
Figure 3. An Increase In The Inflation Target Or The Growth Rate Of The Nominal Money Stock
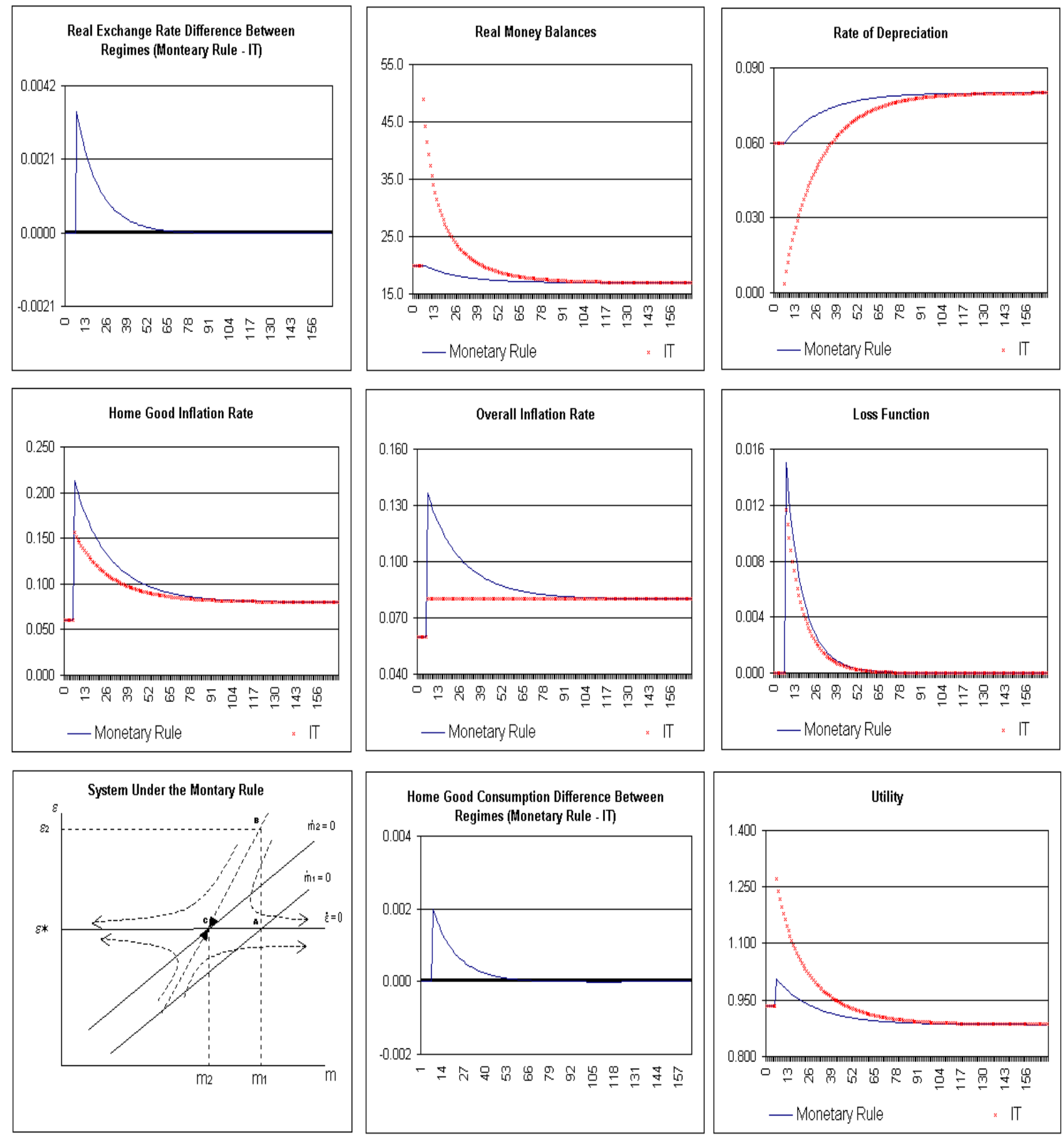